\title{
FAKTOR-FAKTOR YANG MEMPENGARUHI SIKAP PETANI TERHADAP PROGRAM UPSUS PAJALE DI DISTRIK SUKOHARJO
}

\section{FACTORS AFFECTING FARMERS ATTITUDES TOWARD UPSUS PAJALE PROGRAM IN SUKOHARJO DISTRICT}

\author{
Pradite Nimas Ayu A, Suminah, Arip Wijianto \\ Program Studi Penyuluhan dan Komunikasi Pertanian, Fakultas Pertanian \\ Universitas Sebelas Maret Surakarta \\ Jl.Ir.Sutami No.36 A Kentingan Surakarta 57126 Telp./Fax (0271) 637457 \\ Email: praditeayu866@gmail.com/Telp. 081331863249
}

\begin{abstract}
This study aims to study farmer attitude in UPSUS PAJALE program in Sukoharjo regency, to examine the factors that influence farmers attitudes in UPSUS PAJALE program in Sukoharjo regency, to examine the influence of factors influencing farmer attitude on UPSUS PAJALE program in Sukoharjo regency. The basic method of research is quantitative by survey technique. The location of the research is determined purposively in Sukoharjo District, precisely in the outboard village and Sraten (Gatak), Duwet and Menuran (Baki), and Klumprit and Sapen (Mojolaban) villages with the consideration of production in 2015 showing the highest production (Gatak) medium (Tray), and low production (Mojolaban). The sampling method used is proportional random sampling, with a sample size of 80 farmers. The data obtained through interviews, observation, and documentation. Data analysis using multiple linear regression. The result of research shows that the factors that influence attitude are non-formal education category is very high at $76.25 \%$, the influence of other people who are considered high category importance is $57,50 \%$, high category mass media equal to $52,50 \%$, very category experience high of $78.75 \%$, and the economic environment with katogori of $87.50 \%$. There is a significant influence between nonformal education, the influence of others who are considered important, experience, mass media at the level of $95 \%$ confidence and there is no significant influence between the economic environment on farmers attitude on UPSUS PAJALE program.
\end{abstract}

Keyword : Agriculture, Attitude, Farmer, UPSUS PAJALE.

Abstrak: Penelitian ini bertujuan untukmengkaji sikap petani pada program UPSUS PAJALE di Kabupaten Sukoharjo,mengkaji faktor - faktor yang mempengaruhi sikap petani pada program UPSUS PAJALE di Kabupaten Sukoharjo, mengkaji pengaruh faktor - faktor yang mempengaruhi sikap petani pada program UPSUS PAJALE di Kabupaten Sukoharjo. Metode dasar penelitian adalah kuantitatif dengan teknik survei. Lokasi penelitian ditentukan secara purposive di Kabupaten Sukoharjo, tepatnya di Desa tempel dan Sraten (Gatak), Desa Duwet dan Menuran (Baki), dan Desa Klumprit dan Sapen (Mojolaban) dengan pertimbangan hasil produksi pada tahun 2015 menunjukan produksi tertinggi (Gatak), produksi sedang (Baki), dan 


\section{Ayu A, Suminah, Wijianto, Pertanian, Petani, Sikap,,,}

produksi rendah (Mojolaban). Metode pengambilan sampel yang digunakan adalah proportional random sampling, dengan jumlah sampel 80 petani. Data diperoleh melalui wawancara, observasi, dan dokumentasi. Analisis data menggunakan regresi linier berganda. Hasil penelitian menunjukkan bahwa faktor - faktor yang mempengaruhi sikap yaitu pendidikan non formal kategori sangat tinggi sebesar $76,25 \%$, pengaruh orang lain yang dianggap penting kategori tinggi sebesar $57,50 \%$, media massa kategori tinggi sebesar $52,50 \%$, pengalaman kategori sangat tinggi sebesar 78,75\%, dan lingkungan ekonomi dengan katogori sebesar $87,50 \%$. Terdapat pengaruh yang signifikan antara pendidikan non formal, pengaruh orang lain yang dianggap penting, pengalaman, media massa pada taraf kepercayaan 95\% dan tidak terdapat pengaruh yang signifikan antara lingkungan ekonomi terhadap sikap petani pada program UPSUS PAJALE

Kata Kunci : Pertanian, Petani, Sikap, UPSUS PAJALE.

\section{PENDAHULUAN}

Swasembada pangan adalah keadaan suatu negara mampu memenuhi kebutuhannya sendiri dalam bidang pangan. Pada tahun 1980-an di Indonesia pernah mencapai swasembada pangan, walaupun itu hanya untuk swasembada beras. Era reformasi seperti sekarang ini, dalam dunia perekonomian sudah tercampur oleh warna sosial politik dan faktor - faktor lain sehingga membuat kebijakan swasembada pangan mulai terabaikan. Akibatnya sampai saat ini pun swasembada pangan di Indonesia masih belum tercapai. Alasan belum tercapai, karena dilihat dari kondisi dan fakta - fakta yang terjadi, seperti pemerintah yang masih membuka jalur impor. Saat ini bisa dikatakan bahwa politik anggaran pemerintah tidak memihak sektor pertanian. Kurang tercapainya swasembada pangan juga karena beberapa faktor - faktor hambatan, seperti kurang- nya lahan pertanian, pembuatan gedung - gedung yang lebih meluas, benih yang kurang berkualitas, berkurangnya para petani, tidak menentunya cuaca serta harga pupuk yang semakin mahal, dan masih banyak faktor lainnya. Swasembada pangan, ketersediaan serta keamanan pangan (food security) harus diawali dengan kontinuitas dan kecukupan produksi pertanian dalam arti luas. Mewujudkannya peningkatan dalam sektor pertanian tidak dapat melakukannya sendiri, butuh kerjasama semua bidang dan keahlian untuk dapat terlibat didalamnya. Mulai dari peran serta penyuluh pertanian lapang ditingkat desa dan kecamatan serta seluruh penataan kelembagaannya, pemulian atau penakar tanaman atau ternak serta ikan sampai pada keahlian manajerial pemberian pupuk, air, pakan dan pemberantasan hama dan penyakit. Didalamnya juga dapat terlibat berbagai 
industri hilir seperti industri pupuk, pakan ternak, pestisida, serta industri biologi dan kimia dasar. Mempercepat laju pemenuhan kebutuhan pangan ini, penguasaan terhadap keahlian trans genik atau lebih dikenal dengan bioteknologi mutlak diperlukan. Belum lagi industri alat mesin pertanian dapat berkontribusi mempermudah pengelolaanya.

Ketetapan Pemerintah bahwa swasembada berkelanjutan padi, jagung serta swasembada kedelai harus dicapai dalam 3 tahun ke depan, untuk mencapai target tersebut diterapkan Pola Upaya Khusus (UPSUS). UPSUS adalah usaha bersama yang dilakukan secara khusus untuk mencapai target yang telah ditetapkan melalui berbagai pemecahan masalah yang mungkin timbul dalam pencapaian target tersebut. Organisasi pelaksana UPSUS PAJALE sesuai Permentan Nomor 03/2015 ada di semua tingkatan, baik di tingkat pusat, provinsi, kabupaten, kecamatan dan desa.

Program UPSUS tiga komoditas utama padi, jagung, dan kedelai (PAJALE), program ini mulai berjalan di awal tahun 2015, rencananya program kegiatan ini akan berlangsung selama 3 tahun. Program UPSUS PAJALE, segala strategi dan upaya dilakukan untuk peningkatan luas tanam dan produktivitas di daerah-daerah sentra produksi pangan. Program UPSUS dilaksanakan serentak di beberapa provinsi di Indonesia, yaitu Sumatera Utara, Sulawesi Selatan, Jambi, Kalimantan Barat, Kalimantan Selatan, Kalimantan Tengah, Jawa Tengah dan JawaTimur. Menurut Kurniawan (2015) kegiatan pendukung pencapaian target di lapangan benar-benar dilaksanakan secara all in untuk mensukseskan program yaitu dengan penyediaan dana, pengerahan tenaga, perbaikan jaringan irigasi yang rusak, bantuan pupuk, ketersedian benih unggul yang tepat (jenis/varietas, jumlah, tempat, waktu, mutu, harga), bantuan traktor dan alsintan lainnya yang mendukung persiapan, panen dan pasca panen termasuk kepastian pemasarannya.

Kabupaten Sukoharjo merupakan salah satu Kabupaten yang telah melaksanakan program UPSUS PAJALE. Kabupaten Sukoharjo melakukan berbagai usaha antara lain: pembuatan gudang pangan kapasitas 100 ton, pengendalian konversi lahan pertanian, mencetak lahan pertanian baru, intensifikasi sistem pertanian, dan penerapan teknologi pertanian yang dapat meningkatkan produktivitas dan sekaligus mempertahankan kualitas lingkungan. Usaha yang dilakukan bertujuan untuk keberhasilan program UPSUS PAJALE di Kabupaten Sukoharjo.Keberhasilan 
program UPSUS PAJALE dipengaruhi oleh beberapa faktor, antara lain faktor sikap. Sikap yang dimaksud adalah pengetahuan petani tentang program UPSUS PAJALE, pernyataan positif / negatif tentang program UPSUS PAJALE, dan kecenderungan bertindak petani terhadap program UPSUS PAJALE. Sikap petani perlu dikaji karena sikap akan mempengaruhi keberlanjutan atau keberhasilan suatu program. Kabupaten Sukoharjo sebagai pelaksana UPSUS PAJALE penting untuk diteliti untuk mengetahui bagaimana sikap petani yang ada di Kabupaten Sukoharjo terhadap keberhasilan program UPSUS PAJALE yang ada di wilayah tersebut. Selain itu perlu dikaji faktor - faktor apa saja yang mempengaruhi sikap petani terhadap program UPSUS PAJALE di Kabupaten Sukoharjo.

\section{METODE PENELITIAN}

Penelitian ini dilakukan dengan menggunakan metode penelitian kuantitatif. Penelitian kuantitatif memusatkan pada pengumpulan data yang berupa angka-angka untuk kemudian dianalisis dengan menggunakan alat-alat analisis kuantitatif maupun dengan perhitungan matematika. Penelitian kuantitatif memiliki keunggulan yaitu mampu memberikan penilaian yang lebih obyektif. (Sugiyono, 2011).
Penentuan lokasi penelitian dilakukan secara sengaja (purposive) yaitu berdasarkan pertimbanganpertimbangan tertentu disesuaikan dengan tujuan penelitian. Lokasi penelitian yang dipilih adalah Kabupaten Sukoharjo karena dengan pertimbangan bahwa Kabupaten Sukoharjo menempati produktivitas tertinggi padi di Provinsi Jawa Tengah pada tahun 2015.Penelitian ini dilakukan di 3 Kecamatan yaitu Kecamatan Gatak, Kecamatan Baki, dan Kecamatan Mojolaban. Penelitan ini didasarkan hasil produksi padi pada tahun 2016 yang mana produksi tinggi (Gatak), produksi sedang (Baki), dan produksi rendah (Mojolaban).

Populasi adalah keseluruhan atau totalitas gejala yang akan dijadikan subjek penelitian (Sugiyono, 2011). Populasi yang digunakan dalam penelitian ini adalah petani di Kabupaten Sukoharjo.Idrus (2009) menyatakan pada dasarnya penggunaan sampel penelitian diperkenankan dalam prosedur penelitian selama sampel tersebut dapat mewakili populasinya secara baik (respresentatif) serta menggunakan teknik sampel (teknik sampling) yang benar. Penentuan sampel yang digunakan adalah proportional random sampling. Proportional Random Sampling digunakan dengan pertimbangan jumlah masing masing kelompok tidak sama 
jumlahnya (Idrus, 2009).Penentuan jumlah responden untuk masing masing desa dengan rumus $\mathrm{Ni}=\mathrm{Nk} / \mathrm{N}$ $\times 80$ didapatkan hasil yaitu dari kelompok tani Sri Asih I dengan jumlah anggota 32 orang didapat sebanyak 6 orang, kelompok tani Tani subur II dengan jumlah anggota 37 orang didapat sebanyak 7 orang, kelompok tani Rukun 2dengan jumlah anggota 48 orang didapat sebanyak 9 orang, kelompok tani Sri Rejeki dengan jumlah anggota 82 orang didapat sebanyak 16 orang, kelompok tani Dadi luhur dengan jumlah anggota 110 orang didapat sebanyak 21 orang, dan kelompok tani Karya Suburdengan jumlah anggota 110 orang didapat sebanyak 21 orang.

Teknik pengumpulan data diperlukan dalam penelitian ini dikumpulkan dengan menggunakan teknik wawancara, observasi dokumentasi. Metode analisis data menggunakan regresi linier berganda. $U \mathrm{ji}$ validitas didapat semua peratanyaan valid dan uji realibilitas didapat hasil 0,996 yang artinya cukup tinggi. $U \mathrm{ji}$ asumsi klasik menggunakan 3 uji yaitu uji normalitas, uji multikolinearitas, dan uji heteroskedastisitas. Uji normalitas didapat nilai P-value yaitu Asymp.Sig (2-tailed) bernilai lebih besar dari 0.05 sehingga disimpulkan bahwa residual telah memenuhi asumsi distribusi normal.
Uji multikolinearitas didapat nilai VIF berada dibawah 10 dan nilai toleransi mendekati 1 , maka kesimpulan tidak terdapat multikolinieritas.

Tabel 1. Hasil uji multikolinearitas

\begin{tabular}{lcc}
\hline \multicolumn{1}{c}{ VARIABEL } & TOLERANCE & VIF \\
\hline Pendidikan non formal & 0.508 & 1.968 \\
Pengaruh orang lain yang dianggap penting & 0.914 & 1.094 \\
Keterpaan media massa & 0.896 & 1.116 \\
Pengalaman mengikuti program sebelumnya & 0.519 & 1.925 \\
Lingkungan ekonomi & 0.881 & 1.135 \\
\hline \hline
\end{tabular}

Uji heteroskedastisitastitik-titik menyebar dan tidak membentuk pola tertentu yang jelas sehingga tidak terjadi masalah heteroskedastisitas.

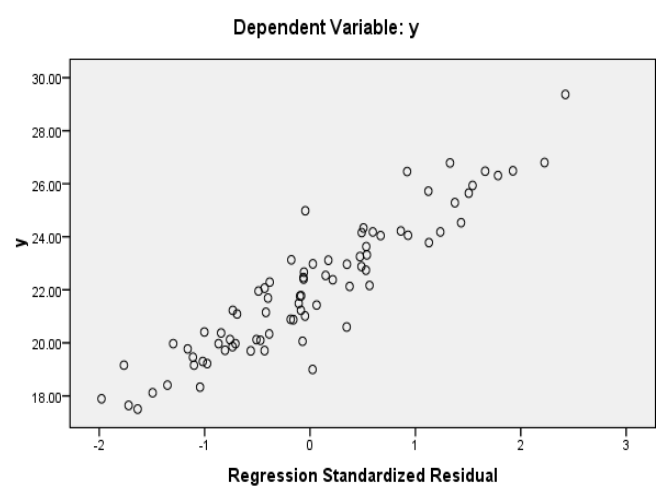

Gambar 2. Hasil analisis uji heteroskedastisitas

\section{HASIL DAN PEMBAHASAN}

Kabupaten Sukoharjo merupakan salah satu Kabupaten yang terletak di Provinsi Jawa Tengah. Kabupaten Sukoharjo memiliki luas wilayah keseluruhan sebesar 46.666 Ha atau sekitar 1,43\% luas wilayah Propinsi Jawa Tengah.penduduk 
kabupaten Sukoharjo sebanyak 869.481 orang, terdiri dari penduduk laki-laki sebanyak 431.086 jiwa dan penduduk perempuan sebanyak 438.395 jiwa.ABT yang diperoleh dari perhitungan sebesar $44,94 \%$ yang berarti bahwa setiap 100 orang penduduk berusia produktif menanggung 44 penduduk yang non produktif. Kondisi ini mencerminkan bahwa ABT di Kabupaten Sukoharjo dikategorikan cukup tinggi. Tingkat pendidikan penduduk di Kabupaten Sukoharjo didominasi oleh penduduk yang berpendidikan tamat SLTA/MA.

Penggunaan lahan di Kabupaten Sukoharjo dibedakan menjadi lahan non pertanian (luas $2.639 \mathrm{Ha}$ ), lahan sawah (luas $20.814 \mathrm{Ha}$ ), lahan kering (luas $22.064 \mathrm{Ha}$ ), perkebunan negara (luas $708 \mathrm{Ha}$ ), hutan (luas 390 $\mathrm{Ha}$ ) dan badan air (luas $51 \mathrm{Ha}$ ) (Status Lingkungan Hidup Daerah, 2015).

Hasil dan pembahasan faktor faktor yang mempengaruhi sikap petani pada program UPSUS PAJALE di Kabupaten Sukoharjo

Menurut Azwar (2003)dalam proses belajar terbentuk dari interaksi sosial. Dalam interaksi sosial, individu membentuk pola sikap tertentu terhadap berbagai objek psikologis yang dihadapinya. Faktor yang mempengaruhi pembentukan sikap adalah: pengaruh orang lain yang dianggap penting, keterpaan media massa, pengalaman mengikuti program sebelumnya. Lingkungan ekonomi mempengaruhi sikap. Djali (2008) mengatakan bahwa situasi dan kondisi ekonomi akan memberikan gemblengan menjadikan insan yang selektif dan hemat dalam pengeluaran pembelanjaan.Menurut Mardikanto (1996) lingkungan ekonomi terdiri dari lembaga pengkreditan yang harus menyediakan kredit bagi petani kecil fasilitas kredit merupakan bagian yang menyatu dengan pengembangan usaha dalam bidang agribisnis. 


\section{Jurnal Agritexts Volume 42 Nomer 1 Mei 2018}

Tabel 2. Faktor - faktor yang mempengaryhi sikap petani dan sikap petani pada program UPSUS PAJALE

\begin{tabular}{|c|c|c|c|c|c|}
\hline No & Karakteristik Responden & Kriteria & Kategori & Jumlah & Prosentase (\%) \\
\hline \multirow[t]{3}{*}{1} & Pendidikan Non Formal & $\geq 10$ kali & Sangat Tinggi & 61 & 76,25 \\
\hline & & 4-6 kali & Rendah & 4 & 5,00 \\
\hline & & 1-3 kali & Sangat Rendah & 00 & 00,00 \\
\hline \multirow[t]{2}{*}{2} & Pengaruh Orang Lain Yang & Selalu & Sangat Tinggi & 22 & 27,50 \\
\hline & & Tidak pernah & Sangat Rendah & 00 & 00,00 \\
\hline \multirow[t]{4}{*}{3} & Keterpaan Media Massa & $5-6$ kali & Sangat Tinggi & 17 & 21,25 \\
\hline & & 3-4 kali & Tinggi & 42 & 52,50 \\
\hline & & 1-2 kali & Rendah & 19 & 23,75 \\
\hline & & Tidak pernah & Sangat Rendah & 3 & 3,75 \\
\hline 4 & Pengalaman Mengikuti Program & Sangat baik & Sangat Tinggi & 63 & 78,75 \\
\hline \multirow{3}{*}{5} & & Baik & Tinggi & 8 & 10 \\
\hline & & Kurang baik & Rendah & 70 & 87,50 \\
\hline & & Sangat Kurang baik & Sangat Rendah & 2 & 2,50 \\
\hline B. & Sikap petani pada program UPSUS & & & & \\
\hline \multirow[t]{4}{*}{1} & Kognitif & Sangat setuju & Sangat Tinggi & 80 & 100 \\
\hline & & Setuju & Tinggi & 0 & 0 \\
\hline & & Tidak Setuju & Rendah & 0 & 0 \\
\hline & & Sangat Tidak Setuju & Sangat Rendah & 0 & 0 \\
\hline \multirow[t]{4}{*}{2} & Afektif & Sangat setuju & Sangat Tinggi & 80 & 100 \\
\hline & & Setuju & Tinggi & 0 & 0 \\
\hline & & Tidak Setuju & Rendah & 0 & 0 \\
\hline & & Sangat Tidak Setuju & Sangat Rendah & 0 & 0 \\
\hline
\end{tabular}

Berdasarkan Tabel 2. dapat diketahui bahwa sikap petani yang meliputi kognitif, afektif, dan konatif pada program UPSUS PAJALE di Kabupaten Sukoharjo yang tergolong dalam kategori sangat tinggi terhadap program ini sebanyak 80 orang dengan presentase $100 \%$. Berdasarkan data tersebut, maka dapat disimpulkan bahwa sikap petani terhadap program UPSUS PAJALE di Kabupaten Sukoharjo sangat baik dan dapat menerima segala kegiatan yang di berikan oleh pemerintah, dengan begitu tujuan program UPSUS PAJALE dapat terlaksana dan hasil program UPSUS
PAJALE yang didapat sesuai dengan tujuan. Menurut Azwar (2003) konsistensi antara kepercayaan sebagai komponen kognitif, perasaan sebagai komponen afektif, dengan tendensi perilaku sebagai komponen konatif seperti itulah yang menjadi landasan dalam menyimpulkan sikap yang dicerminkan oleh jawaban terhadap skala sikap.

Berdasarkan Tabel 2. dapat diketahui bahwapendidikan non formalpetani responden mengikuti kegiatan penyuluhan maupun pelatihan dalam kurun waktu 1 tahun terakhir yaitu sebesar 61 orang $(76,25 \%)$ dikategorikan sangat tinggi 
karena mengikuti $\geq 10$ kali penyuluhan dan pelatihan, petani yang mengikuti 7-9 kali tergolong kategori tinggi sebanyak 15 orang $(18,75 \%)$ dan kategori rendah sebesar 4 orang (5\%) mengikuti $4-6$ kali penyuluhan dan pelatihan. Menurut Hamzah (2015) Pendidikan tidak selamanya dimaknai dengan belajar di dalam kelas (pendidikan jalur formal), karena hanya memberikan semacam landasan kepada manusia.

Berdasarkan Tabel 2.dapat diketahui bahwa pengaruh orang lain yang dianggap (Penyuluh, BABINSA, TPH) pentingpetani responden memiliki pengaruh yangtinggi terhadap tinggi terhadap responden sejumlah 46 orang $(57,50 \%), 22$ orang $(27,50 \%)$ dengan kategori sangat tinggi, dan kategori rendah sebesar 12 orang (15\%). Dipertegas dengan teori Azwar (2003) yaitu orang lain yang disekitar kita merupakan salah satu diantara komponen sosial yang ikut mempengaruhi sikap.

Berdasarkan Tabel 2. dapat diketahui bahwa keterpaan media massa petani responden dalam melaksanakan program UPSUS PAJALE di Kabupaten Sukoharjo adalah kategori tinggi. Kategori tinggi sejumlah 42 orang $(52,50 \%)$ menandakan bahwa petani mengakses dan mendapatkan berita pertanian 5-6 kali dalam 1 minggu, lain hal dengan petani mengakses dan mendapatkan berita pertanian 3-4 kali termasuk dalam kategori sangat tinggi sejumlah $17(21,25 \%)$ tetapi petani lainnya pada kategori yang rendah (1-2 kali) sebesar 19 orang yang presentase nya $23,75 \%$ dan kategori sangat rendah (tidak pernah mengakses) sebesar 3 orang (3,75\%).

Pada umumnya inovasi yang dikomunikasikansecara interpersonal akan lebih cepat diadopsi dari pada apabila inovasi tersebut dikomunikasikan melalui media massa. Hal ini dapat dimengerti karena komunikasi interpersonal lebih intensif dalam menyampaikan anjuran penggunaan hal baru. Sehingga petani akan dapat lebih cepat berubah sikapnya terhadap hal baru tersebut (Pateda, 2010).

Berdasarkan Tabel 2. dapat diketahui bahwa pengalaman mengikuti program sebelumnya petani respondentergolong pada kategori sangat tinggi yaitu sebesar 63 orang petani $(78,75 \%)$, dengan kategori tinggi sebanyak 13 orang $(16,25 \%)$, dan pada kategori rendah sebanyak 4 orang (5\%). Asih (2006) mengatakan bahwa pengalaman merupakan suatu proses pembelajaran dan penambahan perkembangan potensi bertingkah laku baik dari pendidikan formal maupun non formal atau bisa juga diartikan sebagai suatu proses yang membawa seseorang kepada 


\section{Jurnal Agritexts Volume 42 Nomer 1 Mei 2018}

suatu pola tingkah laku yang lebih tinggi.

Berdasarkan Tabel 2. dapat diketahui bahwa lingkungan ekonomi mengikuti program sebelumnya petani responden tergolong pada kategori rendah sebesar $87,50 \%$, pada kategori sangat rendah sebesar $2,50 \%$, dan kategori tinggi sebesar $10 \%$. Lingkungan ekonomi terdiri dari lembaga pengkreditan yang harus menyediakan kredit bagi petani harus kecil, produsen dan penyalur sarana produksi/peralatan tanaman, pedagang serta lembaga pemasaran yang lain, pengusaha industri pengolahan hasil pertanian. Menurut Mardikanto (1996) yaitu lingkungan ekonomi di sekitar petani sangat mempengaruhi kegiatan pertanian. Semua usaha pertanian pada dasarnya adalah kegiatan ekonomi, maka dari itu lingkungan ekonomi

Tabel 3. Tabel Hasil Analisis Faktor - Faktor Yang Mempengaruhi Sikap Petani Pada Program UPSUS PAJALE Secara Parsial

\begin{tabular}{|c|c|c|c|}
\hline Variabel & $\beta$ & Sig & Keterangan \\
\hline (Constant) & 25.463 & 0,000 & \\
\hline Pendidikan non formal (X1) & 1.785 & 0,035 & signifikan \\
\hline Pengaruh orang lain yang dianggap penting (X2) & 0.197 & 0,010 & signifikan \\
\hline Keterpaan media massa $(\mathrm{X} 3)$ & 0.036 & 0,049 & signifikan \\
\hline Pengalaman mengikuti program sebelumnya (X4) & 2.437 & 0,045 & signifikan \\
\hline Lingkungan ekonomi (X5) & 0.188 & 0,060 & Tidak signifikan \\
\hline
\end{tabular}

Sumber: Analisis Data Primer, 2016

Berdasarkan Tabel 3. Didapatkan nilai $\beta$ dengan persamaan regresi $Y=25,463+1,785 X 1+0,197 X 2+$ $0,036 \times 3+2,437 \times 4+0,188 \times 5$. Hasil analisis menunjukkan bahwa faktor faktor yang berpengaruh signifikan terhadap sikap pada program UPSUS PAJALE adalah pendidikan non formal sebesar 0,035; pengaruh orang lain yang dianggap penting sebesar 0,010; media massa sebesar 0,049 ; dan pengalaman sebesar 0,045 , sedangkan lingkungan ekonomi tidak berpengaruh signifikan terhadap sikap sebesar 0,060.
Berdasarkan Tabel 3. Pendidikan non formal (X1) mempengaruhi sikap petani pada program UPSUS PAJALE di Kabupaten Sukoharjo dengan nilai signifikansi 0,035 . Pengaruh yang signifikan pendidikan non formal dengan sikap petani terhadap program UPSUS PAJALE menunjukkan bahwa sikap petani sangat dipengaruhi oleh tingkat pendidikan non formal petani, semakin banyak petani mengikuti kegiatan penyuluhan, sosialisasi dan pelatihan maka akan semakin baik pula sikap petani terhadap program UPSUS PAJALE. 


\section{Ayu A, Suminah, Wijianto, Pertanian, Petani, Sikap, ,}

Kegiatan penyuluhan yang diselenggarakan setiap dua bulan sekali atau berdasarkan kebutuhan petani, materi yang telah disampikan meliputi optimalisasi lahan, pengelolahan tanaman terpadu

padi sawah, pemahaman luas lahan sawah di kecamatan setempat, sekolah lapang, PTT Jagung, PTT Kedelai, pola tanam, pemahaman tentang tanam serentak, tanam benih langsung, pengendalian hama terpadu hingga kebutuhan sarana produksi. Kegiatan penyuluhan biasanya dilakukan pada pertemuan kelompok tani maupun gabungan kelompok tani dan biasanya dilakukan di balai penyuluhan pertanian kecamatan, Dinas Pertanian Kabupaten Sukoharjo, atau di gedung pertemuan.

Berdasarkan Tabel 3. Pengaruh orang lain yang dianggap penting (X2) mempengaruhi sikap petani pada program UPSUS PAJALE dengan nilai signifikansi 0,010. Pengaruh orang lain yang dianggap penting (penyuluh, BABINSA, dan Dinas Pertanian bidang TPH) sudah menjalankan tugasnya dengan baik. Petani mendengar apa yang dianjurkan oleh Penyuluh / BABINSA. Pengaruh orang lain yang dianggap penting disini sangat mempengaruhi petani dengan cara selalu memberikan dorongan kepada petani untuk hasil usaha tani yang meningkat. Contoh kegiatanya seperti penyuluh menjelaskan tentang bagaimana pelaksanaan kalender tanam, diharapkan petani mengerti apa yang diharapkan oleh penyuluh tersebut. Kegiatan kalender tanam ini untuk penanaman serentak. Kegiatan seperti tanam serentak melibatkan BABINSA yang fungsinya adalah untuk mendampingi pelaksanaan tanam serentak tersebut. BABINSA di Kecamatan Gatak, Baki, dan Mojolaban aktif untuk datang ke acara - acara perkumpulan, sehingga petani memberikan respons positif terhadap pelaksanaan tanam serentak. Pengembangan jaringan irigasi di setiap Kecamatan juga memberikan respons positif kepada program UPSUS PAJALE. Dibanggunnya jalan tani merupakan salah satu wujud dari program UPSUS PAJALE.

Berdasarkan Tabel 3. Keterpaan media massa $(\mathrm{X} 3$ ) berpengaruh terhadap sikap petani pada program UPSUS PAJALE dengan nilai signifikansi 0,049. Pesatnya perkembangan teknologi informasi dan komunikasi seperti media massa, menyebabkan terjadi perubahan secara cepat dimana-mana. Media massa sedikit demi sedikit membawa masuk masyarakat ke suatu pola budaya yang baru dan mulai menentukan pola pikir serta budaya perilaku masyarakat. Petani di Kabupaten Sukoharjo mendapatkan informasi lebih banyak dari TV, sudah jarang petani mendapatkan infor- 


\section{Jurnal Agritexts Volume 42 Nomer 1 Mei 2018}

masi tentang usaha tani mereka lewat radio, koran bahkan buletin ataupun majalah. Penggunaan internet masih dirasa kurang untuk mencari informasi tentang usaha tani. Petani kebanyakan berusia lanjut sehingga mereka merasa informasi yang di dapat di TV sudah cukup. Penayangan acara TV seperti saluran Jogja TV atau TVRI yang setiap harinya selalu menayangkan berita - berita terbaru tentang pertanian. Mereka menginginkan agar semua saluran TV memiliki acara seperti Jogja TV ataupun TVRI agar mereka dapat menambah pengetahuan mereka tentang pertanian, karena hanya dengan TV lah mereka dapat mengetahui perkembangan jaman pertanian. Koran yang masih masuk ke desa desa adalah solopos, tetapi biasanya yang hanya berlangganan adalah kantor balai desa sehingga petani apabila ingin membacanya haruslah ke kantor balai desa.

Berdasarkan Tabel 3. Pengalaman mengikuti program sebelumnya (X4) berpengaruh terhadap sikap petani terhadap program UPSUS PAJALEdengan nilai signifikansi 0,045 . Pengalaman petani bertambah melalui beberapa peristiwa yang telah dialami petani melakukan usahataninya.

Pengalaman petani terdapat pengaruh yang signifikan dengan sikap petani terhadap program
UPSUS PAJALE, menandakan bahwa keberagaman pengalaman petani dalam berusahatani akan berpengaruh terhadap penilaian dan pemahaman terkait program UPSUS PAJALE sehingga membentuk sikap yang berbeda. Pengalaman petani dalam berusahatani di Kabupaten Sukoharjo sebagian besar sudah lebih dari 10 tahun, petani dalam setiap program yang dilaksanakan dari pemerintah daerah maupun pemerintah pusat sebagian besar mengikuti dalam program tersebut, serta respon petani terhadap program baik dan sesuai dengan kebutuhan petani, sehingga petani cenderung aktif dan bersikap baik terhadap suatu program maupun inovasi baru.Pengalaman yang ada seperti pelaksanaan program PUAP. Program ini berjalan lancar bahkan seperti desa Menuran, Baki yang awalnya diberi bantuan hanya 100 juta sekarang sudah berkembang menjadi 220 juta. Program ini masih berjalan hingga tahun 2017 diharapkan dapat meningkatkan kesejahteraan petani.

Pembelajaran dari pengalaman program PUAP, pelaksanaan program UPSUS PAJALE dapat terkena dampaknya. Dampak yang dirasa dari Program PUAP adalah dana yang dikumpulkan dapat dipinjamkan petani sesuai dengan giliran mereka. Peminjaman dana ini juga bisa dilakukan apabila mereka terkena 
kendala dalam menjalankan usaha tani mereka.

Berdasarkan Tabel 3. Lingkungan ekonomi (X5) tidak berpengaruh terhadap sikap petani terhadap program UPSUS PAJALE dengan nilai signifikansi 0,060 . Kondisi lingkungan ekonomi yang dirasakan responden yang menyatakan tidak mendukung disebabkan karena responden merasakan kurangnya ketersediaan sarana produksi misalnya bibit, pupuk, dan alat sistem tanam di sekitar tempat tinggalnya dirasa belum mencukupi kebutuhan responden untuk program UPSUS PAJALE ketersediaan kredit di daera

penelitian didapat dari hasil program PUAP. PUAP menyediakan kredit, dan setiap petani disarankan untuk meminjam, tetapi petani banyak mengusahakan usaha taninya dengan cara mandiri.

\section{Uji Simultan (F-test)}

Uji $F$ dikenal dengan Uji serentak atau uji Model/Uji Anova, yaitu uji untuk melihat bagaimana pengaruh semua variabel bebas secara bersama-sama terhadap variabel terikat.Dari data $\mathrm{di}$ atas diperoleh probabilitas 0,000 karena $0,000<0,05$ maka Ho ditolak. Disimpulkan bahwa secara keseluruhan faktor - faktor yang diteliti X1, X2, X3, X4, dan X5 mempengaruhi sikap program UPSUS PAJALE.
Tabel 4. Tabel Uji Simultan (F-test)

\begin{tabular}{cl}
\hline \hline $\mathrm{F}$ & $\mathrm{Sig}$ \\
\hline 44.003 & $.000^{\mathrm{a}}$ \\
\hline \hline
\end{tabular}

\section{Analisis Koefisien Determinasi (Adjusted R Square)}

Model summary terdapat nilai koefisien determinasi R-Square. Tabel ini digunakan untuk menunjukkan variasi variabel dependent $(\mathrm{Y})$ dapat dijelaskan oleh 5 variabel independent $(X 1, X 2, X 3, X 4$, dan $X 5)$. Berdasarkan Tabel 5 . koefisien determinasi. $\mathrm{R}$ square penelitian ini adalah $82,9 \%$ sehingga sikap Program UPSUS PAJALE dipengaruhi oleh faktor - faktor pembentuk sikap yang sisanya $17,1 \%$ dipengaruhi oleh faktor lain.

Tabel 5. Analisis Koefisien Determinasi

\begin{tabular}{ccccc}
\hline \hline Model & $\mathrm{R}$ & R square & Adjusted R square & $\begin{array}{c}\text { Std. Error of } \\
\text { the Estimate }\end{array}$ \\
\hline 1 & $.920^{\mathrm{a}}$ & .847 & .829 & 1.83600 \\
\hline \hline
\end{tabular}

\section{KESIMPULAN DAN SARAN}

\section{Kesimpulan}

Berdasarkan hasil penelitian dan pembahasan yang mengkaji hubungan antara faktor - faktor yang mempengaruhi sikap petani terhadap program UPSUS PAJALE di Kabupaten Sukoharjo yang telah diuraikan, maka dapat ditarik kesimpulan. 


\section{Jurnal Agritexts Volume 42 Nomer 1 Mei 2018}

Sikap petani terhadap program UPSUS PAJALE pada komponen kognitif, afektif, dan konatif terhadap tujuan program, pelaksanaan program, dan hasil program Sikap kognitif semua responden terhadap program UPSUS PAJALE dengan presentase sebesar $100 \%$ atau 80 orang pada kategori sangat tinggi; sikap afektif semua responden terhadap program UPSUS PAJALE dengan presentase sebesar $100 \%$ atau 80 orang pada kategori sangat tinggi; dan sikap konatif semua responden terhadap program UPSUS PAJALE dengan presentase sebesar $100 \%$ atau 80 orang pada kategori sangat tinggi.

Faktor - faktor yang mempengaruhi sikap petani terhadap program UPSUS PAJALE di Kabupaten Sukoharjo yaitu pendidikan non formal (mengikuti penyuluhan dan pelatihan) dengan kategori sangat tinggi sebesar 61 orang $(76,25 \%)$, pengaruh orang lain yang dianggap penting (pengaruh penyuluh, BABINSA, dan Dinas Pertanian bidang Tanaman Pangan dan Hortikultura (TPH)) dengan kategori tinggi sebesar 46 orang $(57,50 \%)$, keterpaan media massa (frekuensi mengakses media elektronik dan media cetak) dengan kategori tinggi sebesar 42 orang $(52,50 \%)$, pengalaman mengikuti program sebelumnya dengan kategori sangat tinggi sebesar 63 orang (78,75\%) dan lingkungan ekonomi (bantuan benih, pupuk, alsintan, dan penyediaan kredit) dengan kategori rendah sebesar 70 orang $(87,50 \%)$.

Pengaruh antara faktor - faktor yang mempengaruhi sikap petani dengan sikap petani pada program UPSUS PAJALE di Kabupaten Sukoharjo: Terdapat pengaruh yang signifikan antara pendidikan non formal petani $(0,035)$, pengaruh orang lain yang dianggap penting $(0,010)$, keterpaan media massa $(0,049)$, pengalaman mengikuti program sebelumnya $(0,045)$ dengan sikap petani pada program UPSUS PAJALE di Kabupaten Sukoharjo. Lingkungan ekonomi petani dengan sikap petani tidak terdapat pengaruh yang signifikan pada program UPSUS PAJALE di Kabupaten Sukoharjo sebesar 0,060.

\section{Saran}

Berdasarkan kesimpulan yang telah diuraikan, maka saran yang dapat disampaikan adalah: Bantuan dari pemerintah khususnya Kementrian Pertanian yang sudah dijanjikan kepada petani sebaiknya memang benar - benar diberikan, dengan bantuan tersebut petani dapat menjalankan usaha taninya lebih baik lagi; pemerintah lebih sering menayangkan acara TV yang berhubungan dengan pertanian agar petani bertambah pengetahuan usaha taninya; dan fungsi pengawasan TPH lebih ditingkatkan dengan 


\section{Ayu A, Suminah, Wijianto, Pertanian, Petani, Sikap,נ,}

cara mensupervisi langsung ke GAPOKTAN tentang pendistribusian bantuan pupuk, benih, dan ALSINTAN agar tidak terjadi penyelewangan. Fungsi pengawasan TPH lebih ditingkatkan dengan cara mensupervisi langsung ke GAPOKTAN tentang pendistribusian bantuan pupuk, benih, dan ALSINTAN agar tidak terjadi penyelewangan.

\section{DAFTAR PUSTAKA}

Azwar, S. 2003. Sikap Manusia : Teori dan Pengukurannya edisi Kedua. Yogyakarta : Pustaka Pelajar.

Djali. 2008. Psikologi Pendidikan. Jakarta : CV Pendoman IImu Jaya.

Idrus, M. 2009. Metode Penelitian IImu Sosial Pendekatan Kualitatif dan Kuantitatif. Jakarta : PT Gelora Aksara Pratama.
Kurniawan, H. 2015. Upaya Khusus (Upsus) Swasembada Pangan 2015 - 2017. http://biogen. litbang.pertanian.go.id/index.p hp/2015/02/upaya-khusus-ups us-swasembada-pangan-20152017/. Diakses pada tanggal 2 Oktober 2016.

Mardikanto, Totok.1996. Penyuluhan Pembangunan Pertanian Pusat Penyuluhan Kehutanan.Jakarta: Departemen Kehutanan.

Hamzah, N. 2015. Pendidikan agama dalam keluarga. Jurnal atturats Vol. 9 No. 2.

Pateda, Mansoer. 2010. Semantik Leksikal. Jakarta: Rineka Cipta.

Sugiyono, 2011. Metode Penelitian Kunatitatif Kualitatif dan $R \& D$. Bandung : ALFABETA. 